\title{
Free-radical depolymerization with metallic catalysts of an exopolysaccharide produced by a bacterium isolated from a deep-sea hydrothermal vent polychaete annelid
}

\author{
A.-C. Petit ${ }^{a, b}$, N. Noiret ${ }^{a,{ }^{*}}$, C. Sinquin ${ }^{b}{ }^{b}$ J. Ratiskol ${ }^{b}$, J. Guézennec $^{b}$ and S. Colliec-Jouault ${ }^{b}$ \\ ${ }^{a}$ Ecole Nationale Supérieure de Chimie de Rennes, Synthèses et Activations de Biomolécules, CNRS \\ UMR 6052, Institut de Chimie de Rennes, Avenue du Général Leclerc, F-35700 Rennes, France \\ ${ }^{\mathrm{b}}$ Institut Français de Recherche pour l'Exploitation de la Mer, Laboratoire de Biotechnologies et \\ Molécules Marines, Département Valorisation des Produits, BP 21105, 44311 Nantes Cedex 3, \\ France \\ *: Corresponding author : noiret@enscrennes.fr
}

\begin{abstract}
Free-radical depolymerization with metallic catalysts has been investigated to depolymerize an exopolysaccharide (EPS), with a high molecular weight $\left(>10^{6} \mathrm{~g} / \mathrm{mol}\right)$, produced by the bacterium Alteromonas macleodii subsp. fijiensis biovar deepsane. Three metals (copper, zinc and manganese) were used either alone or mixed. These metals led to the depolymerization of the high molecular weight bacterial polysaccharide with different efficiency. This study specifies some conditions required to produce, with good reproducibility and yield, EPS derivatives of reduced molecular weight ranging from 100,000 to $20,000 \mathrm{~g} / \mathrm{mol}$. The more influential parameters are specified. This is a first study to find suitable industrial conditions in the presence of these metallic catalysts.
\end{abstract}

Keywords: Metal; H2O2; Free-radical depolymerization; Bacterial exopolysaccharide 


\section{Introduction}

In the past decades, marine polysaccharides have appeared as a new source of biodegradable water-soluble polymers. Most of them are obtained from seaweeds (agar, alginates and carrageenans). More recently, a great interest in producing polysaccharides (especially exopolysaccharides, EPS) by microorganisms has arisen, representing an innovative approach to the biotechnological use of under-exploited resources. EPS often show original structural features that can be modified to design bioactive compounds and improve their specificity (Crescenzi, 1995; Volpi, 2003; Manzoni et al., 2004).

In this context, new bacteria have been collected near deep-sea hydrothermal vents characterized by extreme pressure and temperature conditions (Deming, 1998; Guezennec, 2002). Some thermophilic (Schiraldi and De Rosa, 2002) and also mesophilic EPS-producing strains have been isolated, such as Alteromonas macleodii subsp. fijiensis (Raguénès et al., 1996), Vibrio diabolicus (Raguénès et al., 1997a) and Alteromonas infernus (Raguénès et al., 1997b). These new EPS have innovative structures with great potential for various biomedical purposes. For instance, native EPS secreted by Vibrio diabolicus has been shown to be a strong bone-healing material (Zanchetta et al., 2003) while, after chemical modifications, EPS from Alteromonas infernus have shown anticoagulant properties (Colliec-Jouault et al., 2001) and appeared as new heparin-like candidates.

The EPS HYD 657 (Cambon-Bonavita et al., 2002) from Alteromonas macleodii subsp. fijiensis biovar deepsane collected during the French Hydronaut voyage (Guezennec et al., 1994) has been selected for its abilities to enhance the skin immune defense system (Vacher and Fritsch, 2002) and used in cosmetics as the active ingredient under the Abyssine ${ }^{\circledR} 657$ operation. In order to extend its area of interest, we have carried out investigations to obtain low-molecular-weight fractions from this high-molecular-weight EPS.

In the literature, several methods are described for depolymerizing polysaccharides, such as irradiation (Bertolini et al., 2001), ultrasonic degradation (Portenlanger and Heusinger, 1997), free-radical depolymerization with or without metallic catalysts (Volpi et al., 1992; Nardella et al., 1996; Yang, Li, \& Guan, 2004), acid hydrolysis (Allan and Peyron, 1995; Cheng et al., 1999) or enzymatic depolymerization (Michaud et al., 2003). It has been shown by Guezennec et al. (1998) that the extended acidic hydrolysis of an exopolysaccharide causes severe depolymerization without preserving the monosaccharide ratios while enzymatic depolymerization requires a good knowledge of the structure of the EPS, thus making each EPS a particular case.

From a free-radical depolymerization process, Volpi et al. (1992) showed that it was possible to obtain polysaccharide fractions of low molecular weight (LMW) and constant composition starting from heparin or dermatan sulfate.

This work deals with free-radical depolymerization using metallic catalysts. Here, the metallic catalysts were selected in the interests of cosmetic applications, because their presence can enhance the anti-microbial properties of the EPS formulation to be used in skin and hair care. For the degradation of polysaccharides, free-radical depolymerization is an interesting route because it enables, with reproducibility and constant composition, the extent of the depolymerization to be controlled. Moreover, the reagents are inexpensive and suitable for use on a large scale. In this report, the three catalysts used were copper, zinc and manganese, alone or mixed. The influence of different parameters was investigated for these metals. 


\section{Experimental}

\subsection{Production and characterization of native EPS}

The isolation procedure and characteristics of the HYD 657 strain have previously been reported by Cambon-Bonavita et al. (2002). HYD 657 is composed of neutral sugars (glucose, galactose, rhamnose, fucose and mannose) along with acidic sugars (glucuronic and galacturonic acids) and an unusual sugar identified by GC and GC-mass spectrometry analyses as a 3-0-(1 carboxyethyl)D-glucuronic acid. This polysaccharide, as often observed for EPS, presents a high molecular weight $\left(>10^{6} \mathrm{~g} / \mathrm{mol}\right)$.

\subsection{Molecular weight determination}

Each fraction (2 $\mathrm{mg} / \mathrm{ml}$ ) was analyzed several times by high-performance size-exclusion chromatography (HPSEC) in $0.1 \mathrm{M}$ ammonium acetate at a flow rate of $0.5 \mathrm{ml} / \mathrm{min}$ using a Superdex 200 (Amersham Pharmacia Biotech) column. Calibration was performed with pullulan standards, which are neutral glucans (Interchim), whereas our EPS are charged polysaccharides, so that such calibration does not allow exact measurement of the polysaccharide molecular weight. Area measurements and calculations of Mw (weight-average molecular mass), Mn (number-average molecular mass) and I (polydispersity) were carried out using ARAMIS software (JMBS Développements, Le Fontanil, France).

\subsection{Composition of EPS}

The molar ratio of polysaccharides was determined according to Kamerling et al. (1975) and Montreuil et al. (1986). The monosaccharide residues were analyzed after acidic methanolysis of the polymer and subsequent GLC analyses as trimethylsilyl derivatives.

\subsection{Viscosity determination}

Viscosity was determined by a rotational viscometer Visco Tester GL/R (Haake). The result is a direct reading of the viscosity value in $\mathrm{mPa}$.

\subsection{Conditions of depolymerization of EPS}

Free-radical depolymerization was investigated while varying different parameters $\left(\mathrm{H}_{2} \mathrm{O}_{2} / \mathrm{EPS}\right.$ ratio, flow rate, with or without $\mathrm{pH}$ control) and for three metallic salts: $\mathrm{CuSO}_{4}, 5 \mathrm{H}_{2} \mathrm{O}$ (Janssen Chimica), $\mathrm{ZnSO}_{4}, 7 \mathrm{H}_{2} \mathrm{O}$ (Prolabo) and $\mathrm{MnSO}_{4}, \mathrm{H}_{2} \mathrm{O}$ (Merck). The following protocol is representative of the different experiments:

Two hundred milligrams of EPS HYD 657 was dissolved in water $(100 \mathrm{ml})$ in a reaction vessel and $2 \mathrm{ml}$ of $1.8 \times 10^{-3} \mathrm{M}$ cupric sulfate pentahydrate (corresponding to $0.18 \mathrm{mM}$ of copper for 200 mg of EPS) was added. The temperature was kept at $50^{\circ} \mathrm{C}$. A $0.14 \%$ (w/v) $\mathrm{H}_{2} \mathrm{O}_{2}$ aqueous solution was then added at a flow rate of $30 \mathrm{ml} / \mathrm{h}$. The reaction was stopped after $2 \mathrm{~h}$. The reaction $\mathrm{pH}$ was maintained at $\mathrm{pH} 7$ by continuous addition of $0.1 \mathrm{~N}$ sodium hydroxide. At the end of the reaction, the EPS was reduced by $\mathrm{NaBH}_{4}$. The solution was concentrated, desalinated by ultrafiltration with a 500 Da cutoff membrane (Millipore) and then freeze-dried. Depolymerized EPS fractions were obtained with $70-90 \%$ yields. 
The same experiment was carried out five times with the same batch of production of the EPS to check the reproducibility of the manipulation.

\section{Results}

\subsection{Depolymerization with copper}

Recently, the depolymerization of an EPS produced by Alteromonas infernus has been conducted by a radical process, using the catalytic system metal/ $\mathrm{H}_{2} \mathrm{O}_{2}$. This process allows homogeneous (with a low polydispersity) LMW EPS to be obtained in a single step, and in good yield (ColliecJouault et al, 2001). Here, using the same method, the depolymerization has been performed on the complex EPS HYD 657 from Alteromonas macleodii subsp. fijiensis biovar deepsane, whose repeating unit is thought to be an undecasaccharide with three small side chains. Even though the structure of this EPS is not yet fully known, the repeating unit has been reported to be composed of neutral sugars (glucose, galactose, rhamnose, fucose and mannose) along with acidic sugars (glucuronic and galacturonic acids) and an unusual sugar shown to be a 3-0-(1 carboxyethyl)-Dglucuronic acid.

First, we considered the starting solution of native EPS. Polysaccharides are often used as viscosity enhancers for various industrial purposes because of numerous intra- and intermolecular interactions via hydrogen bonds and, of course, the length of the chains. Another consequence is that temperature is a very important parameter to drive the viscosity of the solution. A good balance must thus be found to avoid the degradation of polymers and to prevent problems of handling and homogeneity.

From these considerations, variations in viscosity vs temperature and concentration were studied (Fig. 1a and 1b). The concentration of the solution of EPS was first set to $2 \mathrm{~g} / \mathrm{L}$ and a linear decrease in the viscosity was observed with increasing temperature, ranging from $160 \mathrm{mPa}$ at $10^{\circ} \mathrm{C}$ to $60 \mathrm{mPa}$ at $60^{\circ} \mathrm{C}$ (Fig. 1a). At $60^{\circ} \mathrm{C}$, an increase in the viscosity was observed with an increase in the EPS concentration but this viscosity was lower than that observed at $30^{\circ} \mathrm{C}$ (Fig. 1b). So, in order to work with a solution presenting a weak viscosity, we decided to perform all experiments at $50^{\circ} \mathrm{C}$ with a concentration of EPS set at $2 \mathrm{~g} / \mathrm{L}$. During the depolymerization process, we also observed a rapid decrease in viscosity with the decrease in Mw (Fig. 2).

In the literature, iron and copper are the two metals most used to depolymerize polysaccharides by free-radical depolymerization. In this work, copper was preferred in order to determine standard conditions before the introduction of other cations. Moreover, copper is of interest for its biological activities in view of further applications in cosmetics.

The influence of the amount of copper cation and the experimental procedure on the depolymerization process was observed. Carboxylic moieties from acids and hydroxyl groups can be involved as electron donors in the chelation of cations, as has been well described in the literature (Angyal, 1989). For instance, a recent study concerning another EPS (Loaëc, Olier \& Guezennec, 1997) showed that metal capture is a chemical, equilibrated and saturable mechanism. In the case of $\mathrm{Zn}^{2+}$, which has an ionic radius very close to $\mathrm{Cu}^{2+}(74 \mathrm{~nm} v \mathrm{~s} 72 \mathrm{~nm})$, the binding capacity is about $80 \mathrm{mg}$ of zinc per gram of polymer. Increasing amounts of copper sulfate were added to a solution of EPS ( $2 \mathrm{~g} / \mathrm{L}$ ), before introduction of $\mathrm{H}_{2} \mathrm{O}_{2}$. For an $\mathrm{H}_{2} \mathrm{O}_{2} / \mathrm{EPS}$ $(\mathrm{w} / \mathrm{w})$ ratio of 0.2 , the system appeared saturated with metal for a concentration of about $2 \mathrm{~g} / \mathrm{L}$. So, high amounts of $\mathrm{Cu}^{2+}$ did not improve depolymerization (Fig. 3). 
In order to limit the binding of copper ion, copper sulfate was added gradually by a peristaltic pump. The experiment was performed with a mass ratio of $\mathrm{H}_{2} \mathrm{O}_{2}$ /EPS of 0.2 , hydrogen peroxide solution was added for one hour at a flow rate of $1 \mathrm{ml} / \mathrm{min}$, and $10 \mathrm{ml}$ of $\mathrm{CuSO}_{4}, 5 \mathrm{H}_{2} \mathrm{O}(4.4 \mathrm{~g} / \mathrm{l})$ was added at a flow rate of $0.2 \mathrm{ml} / \mathrm{min}$. The same experiments were performed with copper sulfate, copper chloride and copper acetate, using the same molar amount of metal. For these three counter-ions, the same results were obtained (i.e. $M_{w}$ was about 20,000 g/mol for $R=0.2$ and $10,000 \mathrm{~g} / \mathrm{mol}$ for $\mathrm{R}=0.4$ ).

Another parameter that could influence the reaction course is $\mathrm{pH}$. A neutral $\mathrm{pH}$ is required for an optimized depolymerization of the polysaccharide backbone by $\mathrm{OH}^{\circ}$ and to avoid an acidic or basic hydrolysis of the polysaccharide. However, during the addition of metallic cation to polysaccharide solutions, a sudden decrease in $\mathrm{pH}$ immediately occurred, due to the chelation process. The $\mathrm{pH}$ of the solution then remained stable with values ranging from 4.0 to 5.2 at $50^{\circ} \mathrm{C}$ depending on the initial concentration of the added cation. Without $\mathrm{pH}$ control, the reproducibility was not very good (Table 1 ) except for high ratios of $\mathrm{H}_{2} \mathrm{O}_{2}$ /EPS (Table 1, entries 3 and 6). For $\mathrm{R}\left(\mathrm{H}_{2} \mathrm{O}_{2}\right.$ /EPS) equal to 0.4 , in each case, final molecular weight was about 15,000 $\mathrm{g} / \mathrm{mol}$ with a good reproducibility. Flow rate and $\mathrm{pH}$ control had no significant influence (Table 1 , entries 3 and 6). The conditions of introduction of $\mathrm{H}_{2} \mathrm{O}_{2}$ were also considered. The radical depolymerization proceeds through the formation of free radicals from hydrogen peroxide and the catalytic action of copper. The active principle is $\mathrm{OH}^{\circ}$ generated in situ with a Fenton reaction, for which $\mathrm{Cu}^{2+}$ is a very effective catalyst, only at trace level. The relative amount of $\mathrm{H}_{2} \mathrm{O}_{2}$, and so of radicals, is one of the keys to control depolymerization. In relation to this point, we showed that a continual addition of $\mathrm{H}_{2} \mathrm{O}_{2}$ was much better than a one-step initial addition to the starting mixture.

In Table 2, the average values corresponding to entry 6 of Table 1 are reported. The monosaccharide content analysis of depolymerized fractions showed some variations, which could imply non-selective degradation of the polymer. Only the contents of galactose, glucose and glucuronic acid are lower in the depolymerized EPS than in the native EPS. However, roughly the same osidic compositions are found with or without $\mathrm{pH}$ control in the LMW EPS and close to the native compound, except for the sugars cited above. In Table 3, the same remarks can be made about the osidic composition for two $\mathrm{H}_{2} \mathrm{O}_{2} / E P S$ ratios (low and high).

\subsection{Addition of other metals}

After radical depolymerization in the presence of metal, a strong sorption of the cations by the EPS presenting well-known chelating properties is observed. So, when required, the elimination of them from the final product needs an additional step using a chelating resin or agent. In the literature, titanium, iron or copper are most often used to catalyze free-radical depolymerization coupling with hydrogen peroxide. In this work, we focus on metallic catalysts (or a mixture of cations) of interest in cosmetic applications. Metals such as iron, copper and zinc at low concentration are known as pro-oxidants in vitro but considered as antioxidants in vivo. So metals play an antioxidant role in vivo by protecting against free radical-induced oxidative damage; they protect against UV radiation, enhance wound healing, contribute to immune and neuropsychiatric functions and decrease the relative risk of cancer and cardiovascular disease (Rostan et al., 2002; Stanner, 2003).

To the best of our knowledge, little is known about the use of zinc or manganese in such processes. First, the same molar amount of zinc or manganese as copper $(0.18 \mathrm{mM}$ for $200 \mathrm{mg}$ of EPS) was introduced into the EPS solution. The temperature was kept constant at $50^{\circ} \mathrm{C}$ and the 
$\mathrm{pH}$ was adjusted to 7 . The results of molar mass determination show that it is possible to depolymerize with zinc sulfate or manganese sulfate alone but the efficiency of the depolymerization appears to be less good than with copper sulfate (Table 4, entries 2 and 3). The monosaccharide contents of the LMW EPS derivatives were very similar whatever the metal used and close to that of the native EPS (Table 5). However, when the depolymerization was performed in the presence of zinc or manganese, the HPSEC chromatograms showed different overlapping peaks, giving EPS derivatives very heterogeneous in size with a high polydispersity. According to the metal used, different trends were observed during depolymerization. Concerning manganese, reproducibility was very low with and without control of $\mathrm{pH}$, under neutral and acidic conditions, respectively. These random results were probably the consequences of solid precipitations of manganese species during the depolymerization.

Next, synergism between copper and the other metals was studied in order to have two metals in the EPS derivatives at the end of the depolymerization process, with the possibility of obtaining some interesting biological properties. Equimolar mixtures of two metals (0.09 mM of each metal for $200 \mathrm{mg}$ of EPS) were tested with and without $\mathrm{pH}$ control. Again, two different types of behavior were observed (Table 4, entries 4 to 7). For the $\mathrm{Cu} / \mathrm{Zn}$ system, the results are very close to those obtained when using copper alone. Copper and zinc are two di-cations with very similar sizes so similar chelation properties could be found. With the $\mathrm{Cu} / \mathrm{Mn}$ system and without $\mathrm{pH}$ control, the molecular weight of the EPS derivatives is very low $\mathrm{Mw}<10,000 \mathrm{~g} / \mathrm{mol}$ (Table 4). Finally, we must say that the mechanism of the free-radical depolymerization with metallic catalysts is not well established. The radical degradation process occurs through the formation of free hydroxyl radical $\mathrm{OH}^{\circ}$ from the hydrogen peroxide-metal redox system. Depending on the polysaccharide structures, these very reactive species mainly attack at the glycosidic bond but, in some cases, direct cleavage of the sugar ring can be observed. Presumably, the site of attack of the hydroxyl radical generated in the aqueous medium during the reaction is localized by the metal used. As has been shown, this EPS contains many carboxylic and hydroxyl groups which could be involved in binding metal ions as weak electron donors (Brown and Lester, 1979). Often a decrease in the content of glucuronic acid is observed, which is not the case for galacturonic acid. Now D-galacturonate complexes are stronger than D-glucuronate ones (Gould and Rankin, 1970), which can be explained by the formation of a complex at the axial position of O-4 in the former. Thus, glucuronic acid would be in more of a position to react with free radicals than galacturonic acid.

\section{Conclusion}

We have prepared, with high reproducibility, low-molecular-weight and size-defined EPS HYD 65 derivatives in the molecular weight $\left(\mathrm{M}_{\mathrm{w})}\right.$ range from 100,000 to 20,000 g/mol, depending on the catalytic system and experimental conditions. Copper was found to be a good catalyst whereas zinc and manganese used alone were less efficient. However, synergies between the different metals were also studied and depolymerization was shown to be more efficient when a mixture of copper and zinc or manganese was used. To control the free-radical production, and thus the efficiency and the reproducibility of the depolymerization, the most other influential parameters were $\mathrm{pH}$ control and the concentration of $\mathrm{H}_{2} \mathrm{O}_{2}$. This latter parameter can be modulated both by the flow rate of $\mathrm{H}_{2} \mathrm{O}_{2}$ and the mass ratio $\mathrm{H}_{2} \mathrm{O}_{2} /$ EPS. A low flow rate of $\mathrm{H}_{2} \mathrm{O}_{2}$ and a neutral $\mathrm{pH}$ (except for the mixture manganese sulfate-copper sulfate) are essential both to control the depolymerization (fractions above $20,000 \mathrm{~g} / \mathrm{mol}$ ) and to obtain good reproducibility. 
Now, studies are underway to explore the potential of depolymerized fractions, especially some of their biological properties.

\section{Acknowledgements}

The authors wish to thank the Lanatech subsidiary of Atrium Biotechnologies for financial support.

\section{References}

Allan, G.G., \& Peyron, M. (1995). Molecular weight manipulation of chitosan I: kinetics of depolymerization by nitrous acid. Carbohydrate Research, 277(2), 257-282.

Angyal, S.J. (1989). Complexes of metal cations with carbohydrates in solution. Advances in Carbohydrate Chemistry and Biochemistry. Edited by Tipson R.S. and Horton D. Academic Press, 47, 1-43.

Bertolini, A.C., Mestres, C., Colonna, P. \& Raffi, J. (2001). Free radical formation in UV- and gamma-irradiated cassava starch. Carbohydrate Polymers, 44(3), 269-271.

Brown, M.J., \& Lester, J.N. (1979). Metal removal in activated sludge: the role of bacterial extracellular polymers. Water Research, 13, 817-837.

Cambon-Bonavita, M.A., Raguenes, G., Jean, J., Vincent, P. \& Guezennec, J. (2002). A novel polymer produced by a bacterium isolated from a deep-sea hydrothermal vent polychaete annelid. Journal of Applied Microbiology, 93(2), 310.

Chapuis, Ph. \& Favier, A. (1995). La cosmétologie. In Les oligoéléments en nutrition et thérapeutique, pp. 355-362. Paris: Editions Médicales Internationales Lavoisier.

Cheng, M.C., Wang, K.T., Inoue, S., Inoue, Y., Khoo, K.H. \& Wu, S.H. (1999). Controlled acid hydrolysis of coliminic acid under microwave irradiation. Analytical Biochemistry, 267(2), 287-293.

Colliec Jouault, S., Chevolot, L., Helley, D., Ratiskol, J., Bros, A., Sinquin, C., Roger, O. \&

Fischer, A.M. (2001). Characterization, chemical modifications and in vitro anticoagulant

properties of an exopolysaccharide produced by Alteromonas infernus. Biochimica et Biophysica

Acta, 1528 (2-3), 141-151.

Crescenzi, V. (1995). Microbial polysaccharides of applied interest: ongoing research activities in

Europe. Biotechnology Progress, 11(3), 251-259.

Deming, J.W. (1998). Deep ocean environmental biotechnology. Current Opinion in Biotechnology, 9(3), 283-287.

Loaëc, M., Olier \& R., Guezennec, G. (1997). Uptake of lead, cadmium and zinc by a novel bacterial exopolysaccharide. Water Research, 31(5), 817-837.

Gould, R.O. \& Rankin, A.F. (1970). Calcium complexes of uronic acid monomers. Journal Of the Chemical Society D: 489-490.

Guezennec, J., Pignet, P., Raguenes, G., Deslandes, E., Lijour, Y. \& Gentric, E. (1994). Preliminary chemical characterization of unusual eubacterial exopolysaccharides of deepsea origin, Carbohydrate Polymers, 24 (4), 287-294.

Guezennec, J., Pignet, P., Lijour, Y., Gentric, E., Ratiskol, J. \& Colliec-Jouault S. (1998). Sulfation and depolymerization of a bacterial exopolysaccharide of hydrothermal origin. Carbohydrate Polymers, 37(1), 19-24. 
Guezennec, J. (2002). Deep-sea hydrothermal vents: A new source of innovative bacterial exopolysaccharides of biotechnological interest? Journal of Industrial Microbiology \& Biotechnology, 29(4), 204-208.

Kamerling, J.P, Gerwig, G.J., Vliegenhart, J.F.G., Clamp, J.R. (1975). Characterization by gas liquid chromatography mass spectrometry of pertrimethylsilyl glycoside obtained in methanolysis of glycoproteins and glycolipids. Biochemical Journal, 151, 491-495.

Montreuil, J., Bouquelet, S., Debray, H., Fournet, B., Spik, G. Strecker, G. (1986). In Carbohydrate Analysis: A practical approach, Glycoproteins, 143-204, IRL Press Oxford, Washington, DC.

Manzoni, M., Rollini, M., Piran, E. \& Parini, C. (2004) Preliminary characterization of an Escherichia coli K5 lyase-deficient strain producing the K5 polysaccharide. Biotechnology Letters, 26(4), 351-356.

Martini, M.C. \& Seiller, M. (1999), Actifs et additifs en cosmétologie (pp. 210). Paris: Editions Médicales Internationales Lavoisier.

Nardella, A., Chaubet, F., Boisson Vidal, C., Blondin, C., Durand, P., Jozefonvicz, J. (1996). Anticoagulant low molecular weight fucans produced by radical process and ion exchange chromatography oh high molecular weight fucans extracted from the brown seaweed Ascophyllum nodosum. Carbohydrate Research, 289, 201-208.

Portenlänger, G. \& Heusinger H. (1997) The influence of frequency on the mechanical and radical effects for the ultrasonic degradation of dextranes. Ultrasonics Sonochemistry, 4(2), 127-130.

Raguénès, G., Pignet, P., Gauthier, G., Peres, A., Christen, R., Rougeaux, H., Barbier, G., \& Guezennec, J. (1996). Description of a new polymer-secreting bacterium from a deep-sea hydrothermal vent, Alteromonas macleodii subsp. fijiensis, and preliminary characterization of the polymer. Applied and Environmental Microbiology, 62, 67-73.

Raguénès, G., Christen, R., Guezennec, J., Pignet, P., \& Barbier, G. (1997a). International Journal of Systematic Bacteriology, 47, 989-995.

Raguénès, G., Peres, A., Ruimy, R., Pignet, P., Christen, R., Loaec, M., Rougeaux, H., Barbier, \& G., Guezennec, J. (1997b). Journal of Applied Microbiology, 82, 422-430.

Rostan, E.F., DeBuys, H.V., Madey, D. L., \& Pinnell, S.R. (2002). Evidence supporting zinc as an important antioxidant for skin. International Journal of Dermatology, 41, 606-611.

Rougeaux, H., Guezennec, J., Russell, W. Carlson, Kervarec, N., Pichon, R. \& Talaga, P. (1999). Structural determination of the exopolysaccharide of Pseudoalteromonas strain HYD 721 isolated from a deep-sea hydrothermal vent. Carbohydrate Research, 315 (3-4), 273-285.

Schiraldi, C. \& De Rosa, M. (2002). The production of biocatalysts and biomolecules from extremophiles. Trends in Biotechnology, 20(12), 515-521.

Stanner, S. (2003). Metal matters: a conference on iron, copper and zinc. Nutrition Bulletin, 28, 215-220.

Vacher, A.M., Fritsch, M.C. US-Patent 2002187167, 2002.

Vincent, P., Pignet, P., Talmont, F., Bozzi, L., Fournet, B., Guezennec, J., Jeanthon, C., \& Prieur, D. (1994). Production and characterization of an exopolysaccharide excreted by a deep-sea hydrothermal vent bacterium isolated from the polychaete annelid. Alvinella pompejana. Applied and Environmental Microbiology, 60, 4134-4141.

Volpi, N., Mascellani G., \& Bianchini P. (1992). Low molecular weight heparins (5kDa) and oligoheparins $(2 \mathrm{kDa})$ Produced by gel permeation enrichment or radical process: comparison of structures and physicochemical and biological properties. Analytical Biochemistry, 200, 100-107. 
Volpi, N. (2003). Milligram-scale preparation and purification of oligosaccharides of defined length possessing the structure of chondroitin from defructosylated capsular polysaccharide K4. Glycobiology, 13, 635-640.

Yang, Z., Li, J.P., \& Guan, H.S. (2004). Preparation and characterization of oligomannuronates from alginate degraded by hydrogen peroxide. Carbohydrate Polymers, 58, 115-121.

Zanchetta, P., Lagarde, N., \& Guezennec, J. (2003). A new bone-healing material: a hyaluronic acid-like bacterial exopolysaccharide. Calcified Tissue International, 72, 74-79. 
Table 1

Molecular weight, polydispersity and reproducibility according to different $\mathrm{H}_{2} \mathrm{O}_{2} / \mathrm{EPS}$ ratios and $\mathrm{H}_{2} \mathrm{O}_{2}$ flow rates

\begin{tabular}{ccccccc}
\hline Entry & $\begin{array}{c}\mathrm{H}_{2} \mathrm{O}_{2} \\
\text { flow rate } \\
(\mathrm{ml} / \mathrm{min})\end{array}$ & $\mathrm{R}\left(\mathrm{H}_{2} \mathrm{O}_{2} / \mathrm{EPS}\right)$ & $\begin{array}{c}\mathrm{pH} \\
\text { control }\end{array}$ & $\begin{array}{c}\mathrm{M}_{\mathrm{w}} \\
\left(\mathrm{x} \mathrm{10} 0^{3} / \mathrm{mol}\right)\end{array}$ & $\mathrm{I}_{\mathrm{p}}(\mathrm{Mw} / \mathrm{Mn})$ & $\begin{array}{c}\text { Reproducibility } \\
(\mathrm{n}=4)\end{array}$ \\
\hline 1 & 1.0 & 0.1 & Yes & $40-130$ & - & bad \\
2 & 1.0 & 0.2 & Yes & $20-50$ & 2.0 & bad \\
3a & 1.0 & 0.4 & Yes & $10-20$ & 2.5 & good \\
3b & 1.0 & 0.4 & No & $15-25$ & 2.5 & good \\
$4 \mathrm{a}$ & 0.5 & 0.1 & Yes & 40 & 2.0 & good \\
4b & 0.5 & 0.1 & No & $60-100$ & - & bad \\
$5 \mathrm{a}$ & 0.5 & 0.2 & Yes & 20 & 2.4 & good \\
$5 \mathrm{~b}$ & 0.5 & 0.2 & No & $45-100$ & - & bad \\
6a & 0.5 & 0.4 & Yes & 10 & 2.5 & good \\
6b & 0.5 & 0.4 & No & 20 & 2.5 & good \\
\hline
\end{tabular}

$\mathrm{n}=$ number of experiments

Table 2

Monosaccharide contents of the low-molecular-weight EPS derivatives obtained after depolymerization for an $\mathrm{H}_{2} \mathrm{O}_{2}$ /EPS ratio of 0.4 with or without $\mathrm{pH}$ control and in the presence of copper as catalyst, and compared to the native EPS

\begin{tabular}{cccccccccr}
\hline EPS & $\begin{array}{c}\text { Rha } \\
\%\end{array}$ & $\begin{array}{c}\text { Fuc } \\
\%\end{array}$ & $\begin{array}{c}\text { Gal } \\
\%\end{array}$ & $\begin{array}{c}\text { Glu } \\
\%\end{array}$ & $\begin{array}{c}\text { Man } \\
\%\end{array}$ & $\begin{array}{c}\text { GlcA } \\
\%\end{array}$ & $\begin{array}{c}\text { GalA } \\
\%\end{array}$ & $\begin{array}{c}\text { Mw } \\
\left(\times 10^{3} \mathrm{~g} / \mathrm{mol}\right)\end{array}$ & Ip \\
\hline Native & 3.4 & 1.8 & 21.7 & 12.3 & 1.8 & 6.1 & 7.3 & 3000 & $>5$ \\
pH control & 2.3 & 1.4 & 10.5 & 7.6 & 1.3 & 2.3 & 6.1 & 10 & 2.5 \\
No pH control & 2.3 & 1 & 15.1 & 9.8 & 1.4 & 8.4 & 6.5 & 20 & 2.5 \\
\hline
\end{tabular}

Rha, rhamnose; Fuc, fucose; Gal, galactose; Glu, glucose; Man, mannose; GlcA, glucuronic acid and GalA, galacturonic acid.

Table 3

Monosaccharide contents of the low-molecular-weight EPS derivatives obtained for two $\mathrm{H}_{2} \mathrm{O}_{2}$ /EPS ratios $(\mathrm{R}=0.2$ and $\mathrm{R}=0.4)$ in the presence of copper as catalyst and compared to the native EPS

\begin{tabular}{rccccccccc}
\hline EPS & $\begin{array}{c}\text { Rha } \\
\%\end{array}$ & $\begin{array}{c}\text { Fuc } \\
\%\end{array}$ & $\begin{array}{c}\text { Gal } \\
\%\end{array}$ & $\begin{array}{c}\text { Glu } \\
\%\end{array}$ & $\begin{array}{c}\text { Man } \\
\%\end{array}$ & $\begin{array}{c}\text { GlcA } \\
\%\end{array}$ & $\begin{array}{c}\text { GalA } \\
\%\end{array}$ & $\begin{array}{c}\mathrm{M}_{\mathrm{w}} \\
\left(\times 10^{3} \mathrm{~g} / \mathrm{mol}\right)\end{array}$ & $\mathrm{I}_{\mathrm{p}}$ \\
\hline Native & 3.4 & 1.8 & 21.7 & 12.3 & 1.8 & 6.1 & 7.3 & 3000 & $>5$ \\
$\mathrm{R}=0.2$ & 2.7 & 1.9 & 15.5 & 9.5 & 2.1 & 2.6 & 7.1 & 20 & 2.4 \\
$\mathrm{R}=0.4$ & 3 & 1.7 & 11.2 & 7.6 & 1.3 & 2.8 & 7.2 & 10 & 2.5 \\
\hline
\end{tabular}

Rha, rhamnose; Fuc, fucose; Gal, galactose; Glu, glucose; Man, mannose; GlcA, glucuronic acid and GalA, galacturonic acid. 
Table 4

Molecular weight and polydispersity according to the metal used, $\mathrm{H}_{2} \mathrm{O}_{2} / \mathrm{EPS}$ ratio and $\mathrm{pH}$ control (flow $=0.5 \mathrm{~mL} / \mathrm{min}$ )

\begin{tabular}{|c|c|c|c|c|c|}
\hline Entry & Metal(s) & $\mathrm{R}\left(\mathrm{H}_{2} \mathrm{O}_{2} / \mathrm{EPS}\right)$ & pH control & $\begin{array}{c}\mathrm{Mw} \\
\left(\mathrm{x} 10^{3} \mathrm{~g} / \mathrm{mol}\right)\end{array}$ & $\mathrm{Ip}(\mathrm{Mw} / \mathrm{Mn})$ \\
\hline $1 \mathrm{a}$ & $\mathrm{Cu}$ & 0.4 & Yes & 10 & 2.4 \\
\hline $1 \mathrm{~b}$ & & 0.4 & No & 20 & 2.5 \\
\hline \multirow[t]{2}{*}{2} & $\mathrm{Zn}$ & 0.4 & Yes & $10-100$ & - \\
\hline & & 0.4 & No & 100 & 3 \\
\hline \multirow[t]{2}{*}{3} & Mn & 0.4 & Yes & $20-300$ & 3.5 \\
\hline & & 0.4 & No & $12-430$ & - \\
\hline \multirow[t]{2}{*}{4} & & 0.2 & Yes & 25 & 2 \\
\hline & $\mathrm{Cu}+\mathrm{Zn}$ & 0.2 & No & $75-100$ & - \\
\hline \multirow[t]{2}{*}{5} & & 0.4 & Yes & 10 & 2.2 \\
\hline & & 0.4 & No & & \\
\hline 6 & & 0.2 & Yes & & \\
\hline & $\mathrm{Cu}+\mathrm{Mn}$ & 0.2 & No & 10 & 2.2 \\
\hline \multirow[t]{2}{*}{7} & & 0.4 & Yes & $50-70$ & - \\
\hline & & 0.4 & No & $<10$ & 2.0 \\
\hline
\end{tabular}

Table 5

Monosaccharide contents of the LMW EPS derivatives obtained after depolymerization with different metals and $\mathrm{R}\left(\mathrm{H}_{2} \mathrm{O}_{2} / \mathrm{EPS}\right)=0.4$

\begin{tabular}{lcccccccccc}
\hline EPS & Metal & $\begin{array}{c}\text { Rha } \\
\%\end{array}$ & $\begin{array}{c}\text { Fuc } \\
\%\end{array}$ & $\begin{array}{c}\text { Gal } \\
\%\end{array}$ & $\begin{array}{c}\text { Glu } \\
\%\end{array}$ & $\begin{array}{c}\text { Man } \\
\%\end{array}$ & $\begin{array}{c}\text { GlcA } \\
\%\end{array}$ & $\begin{array}{c}\text { GalA } \\
\%\end{array}$ & $\begin{array}{c}\mathrm{M}_{\mathrm{w}} \\
\left(\mathrm{x} 10^{3} \mathrm{~g} / \mathrm{mol}\right)\end{array}$ & $\mathrm{I}_{\mathrm{p}}$ \\
\hline Native & - & 3.4 & 1.8 & 21.7 & 12.3 & 1.8 & 6.1 & 7.3 & 3000 & - \\
LMW EPS & $\mathrm{Cu}$ & 3.0 & 1.7 & 11.2 & 7.6 & 1.3 & 2.8 & 7.2 & 10 & 2.5 \\
LMW EPS & $\mathrm{Zn}$ & 2.8 & 1.5 & 17.7 & 9.8 & 1.3 & 4.8 & 7.3 & 21.5 & 4.8 \\
LMW EPS & $\mathrm{Mn}$ & 2.3 & 1.3 & 18.0 & 9.0 & 1.8 & 4.3 & 7.4 & 25 & $\mathrm{a})$ \\
\hline
\end{tabular}

a) three peaks 
(a)

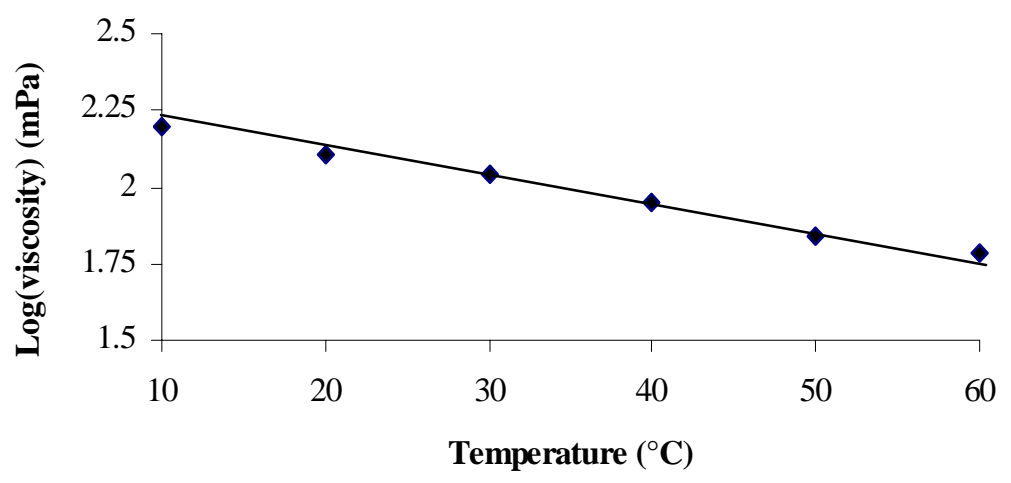

(b)

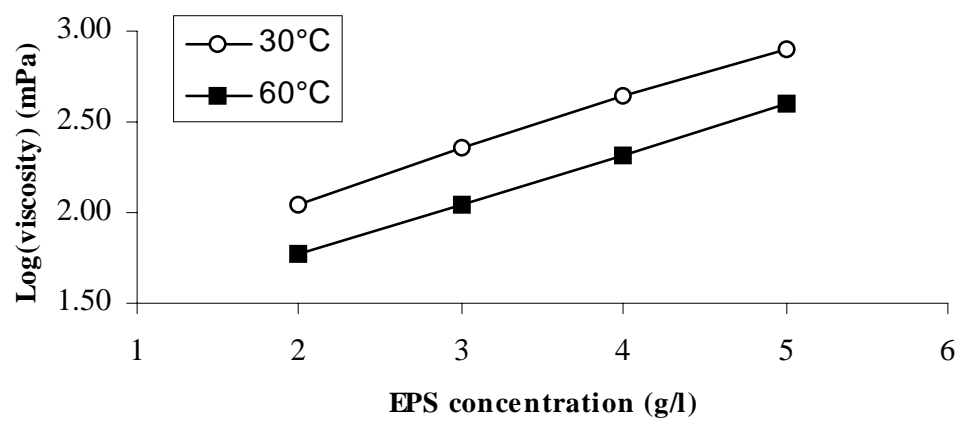

Fig. 1. Evolution of viscosity vs temperature (a) (EPS concentration $=2 \mathrm{~g} / \mathrm{l}$ ) and concentration (b) $\left(\mathrm{T}=30^{\circ} \mathrm{C}\right.$ and $\left.60^{\circ} \mathrm{C}\right)$. A logarithmic dependence is showed in both cases. 


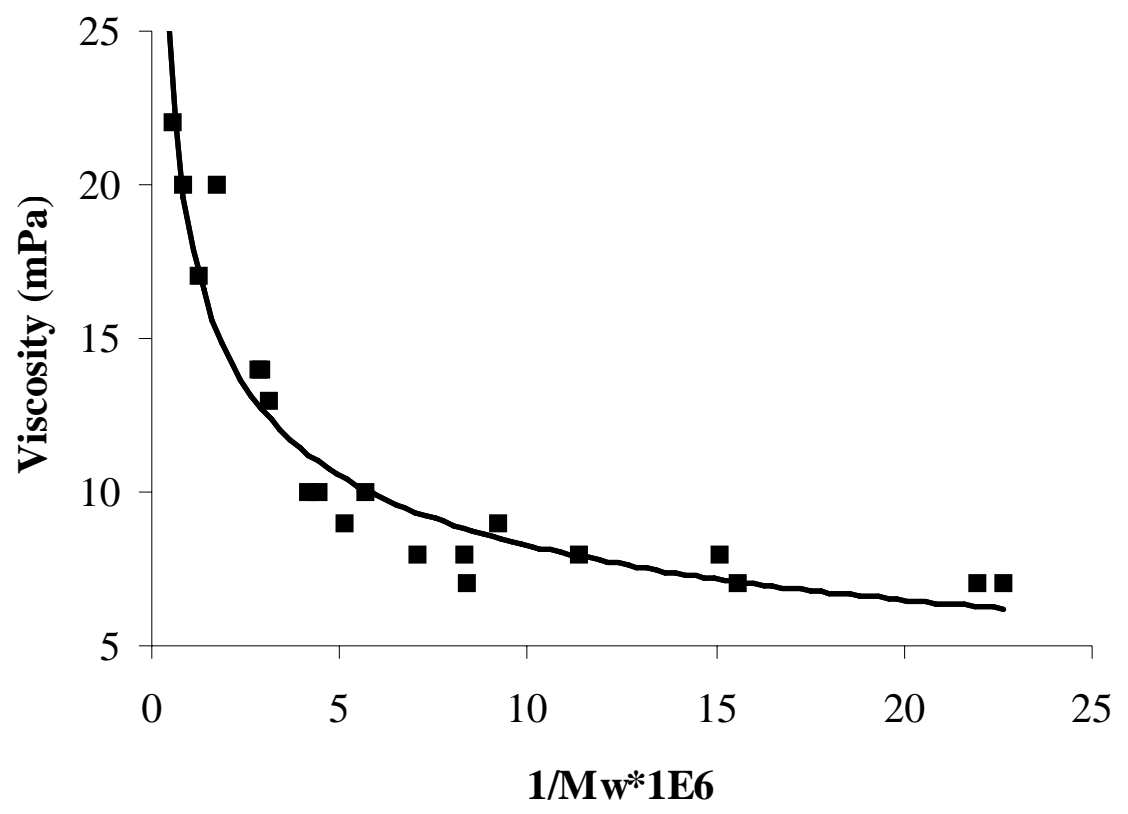

Fig. 2. Relation between viscosity vs $1 / \mathrm{Mw}$. Under a Mw of about 200,000 $\mathrm{g} / \mathrm{mol}$, the viscosity of the solution remains constant at about $7 \mathrm{mPa}$. 


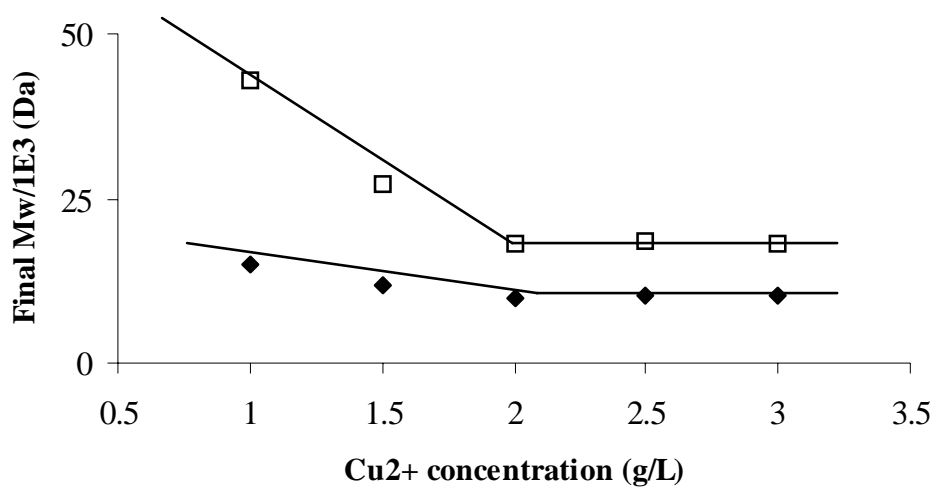

Fig. 3. Influence of $\mathrm{Cu}^{2+}$ on depolymerization. For an EPS concentration of $2 \mathrm{~g} / \mathrm{l}$ and an $\mathrm{H}_{2} \mathrm{O}_{2} /$ EPS ratio of 0.2 , the limiting concentration of $\mathrm{Cu}^{2+}$ is about $2 \mathrm{~g} / \mathrm{l}$. 